\title{
Major hazards associated with cave mining: are they manageable?
}

\author{
G Flores-Gonzalez Newcrest Mining Limited, Australia
}

\begin{abstract}
Cave mining methods have become viable and preferred mass underground mining options where the objectives are low cost and high production rates. However, the cave mining industry has already entered into a less certain period or environment where some of the current cave mining options are already showing not to be fully suitable to achieving the envisaged low cost and high productivity objectives. This environment includes deeper and sometimes blind deposits (up to 1,400 $\mathrm{m}$ from surface), lower average grade deposits, harder and heterogeneous rock masses, higher stress and, in some cases, higher temperature environments. This is requiring design of greater caving block heights, demand for increased safety and productivity, and escalating mining costs (capital and operating). In addition, there is increasing shortage of technical skills, capital becoming more difficult to access, and communities desiring higher environmental standards.

In this new cave mining environment, several hazards are identified that can have critical impact on safety, productivity and profitability. It is necessary, therefore, that these major hazards be acknowledged, and the likelihood of their occurrence be evaluated and minimised during the deposit investigation, mine design and planning, and operational stages of the caving process. These are not trivial issues and can have the most serious of consequences. They demand serious managerial and technical attention (Brown 2012).

This paper focuses on the major hazards associated with the caving process which are rockbursts, air blast, subsidence and inrushes. These hazards are experienced during the cave establishment (development, drawbell opening, undercutting), cave propagation, cave breakthrough to surface, and steady state production stages. Measures to manage these risks aiming to reduce their consequences are also discussed.
\end{abstract}

Keywords: hydrofracturing, intensive preconditioning, post-undercutting, rockburst, air blast, inrush, subsidence, dynamic ground support

\section{Introduction}

The increasing demand of strategic mineral commodities such as copper, gold and molybdenum will require application of safe, productive and profitable mining methods. Cave mining is an example of such methods. Unfortunately, these commodities are increasingly being found in deep deposits with geological and geotechnical environments significantly different to past and current mining conditions where caving methods have been applied. The corresponding major hazards are often associated with cave establishment, cave propagation, cave breakthrough to surface and cave steady state production processes; thereafter, they need to be better understood and managed appropriately.

Block caving is a highly productive, low-cost underground mass mining method. In block caving, the full orebody or an approximately equidimensional block of ore is undercut to initiate caving. The undercut zone is drilled and blasted progressively, and some broken ore is drawn off to create a void into which initial caving of the overlying ore can take place. As more broken ore is drawn progressively following cave initiation, the cave propagates upwards through the orebody or block until the overlying rock also caves and surface subsidence occurs (Brown \& Chitombo 2007).

The broken ore is removed through the extraction level developed below the undercut level and connected to it by drawbells through which the ore gravitates to drawpoints on the extraction level (Figure 1). In current block caving operations, the broken ore is removed from the drawpoints by load-haul-dump (LHD) vehicles. 
From the extraction level, the ore is transported or transferred to the underground crusher and then to the haulage level and out of the mine.

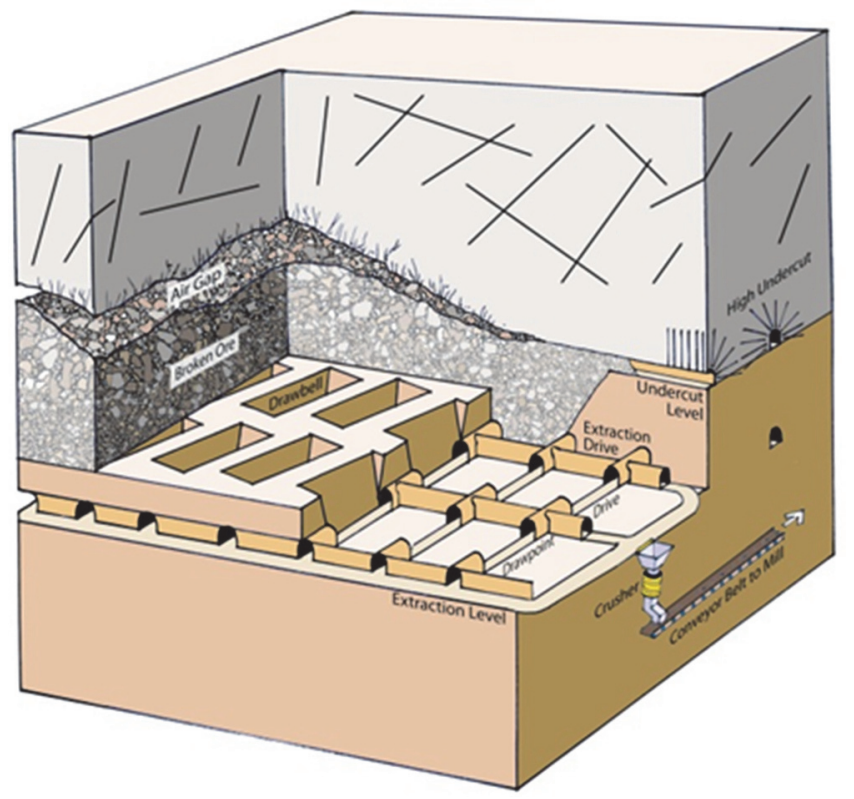

Figure 1 Illustration of the block caving mining method (Flores 2014)

There is now a tendency for block caving to be used in stronger orebodies which produce coarser fragmentation than did the traditional applications of this mining method (Flores 2014). This enables more widely spaced drawpoints and larger equipment to be used. However, there are dangers that the fragmentation may be too coarse to be handled by the drawpoints or the LHD equipment, and that caving may become stalled in these stronger orebodies, particularly those with limited footprints (Brown 2012).

Block caving is inherently risky, and large amounts of development and expenditure are required before production can commence. Furthermore, the nature of the underground development is such that, if caving does not work satisfactorily, making a change to another method of mining is difficult to achieve economically. In addition, block caving is also subject to a range of other risks normally associated with modern large-scale, deep mining, hard rock masses and high stresses.

Among those risks is a group that is generally referred to as major operational hazards which includes rockbursts, air blasts, subsidence and inrushes (Flores et al. 2004). If not adequately managed, each of these hazards has the potential to impact on safety and/or mining business. It is necessary, therefore, that these major operational hazards be recognised, and the likelihood of their occurrence be evaluated and minimised during the investigation, design, and operational stages of a block caving project (Brown 2012). These are not trivial issues, and the experience has demonstrated that they can have the most serious of consequences. They demand serious managerial and technical attention. However, experience shows that, with that attention, their occurrence can be minimised and their effects managed (Brown \& Chitombo 2007).

Globally, the number of current and future cave mines which are in operation or have been planned for depths of greater than 1,400 m include Codelco El Teniente and Chuquicamata Underground Mine Project, Freeport Deep Mill Level Zone, Grasberg underground mine and Henderson; Newcrest Cadia East, Telfer and Golpu; Palabora Mining Company Palabora mine; Luossavaara-Kiirunavaara Aktiebolag Kiruna mine and Rio Tinto Oyu Tolgoi and Resolution. Most of these operating mines are already experiencing some of the aforementioned major operational hazards. 


\section{The major operational hazards associated with caving processes}

The major operational hazards that are envisaged and/or already being experienced by a number of the operations listed earlier are rockbursts, air blasts, subsidence and inrushes. These have been experienced during the cave establishment, cave propagation, cave breakthrough to surface, and cave steady state production processes (Figure 2).

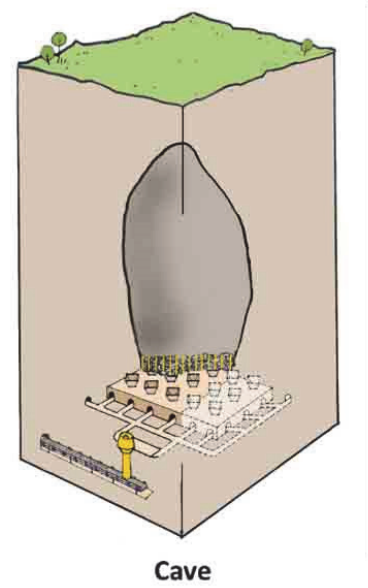

Establishment

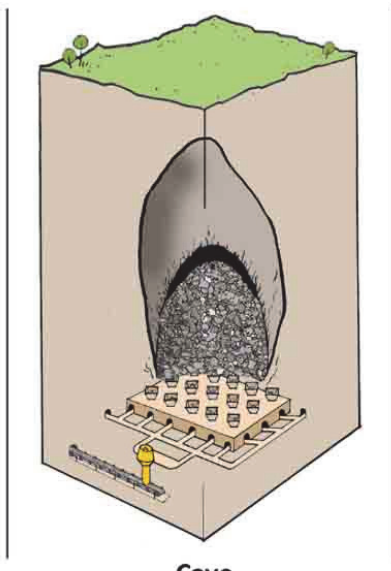

Propagation

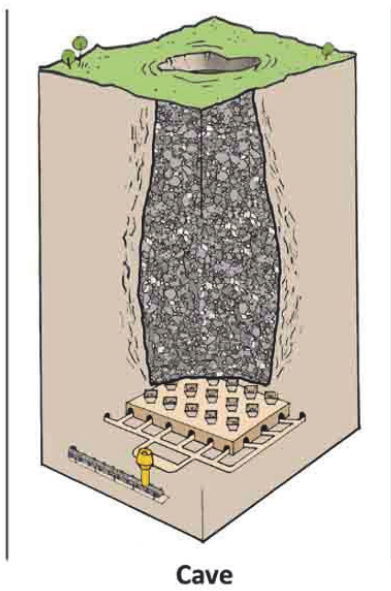

Breakthrough

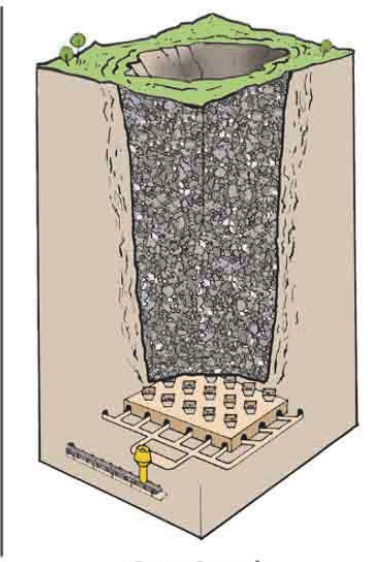

Cave Steady

State Production

Figure 2 Cave mining processes

\subsection{Cave establishment}

Cave establishment is a term used to describe the development of the footprint and underground infrastructure, drawbell opening and undercutting the block (Figure 3).

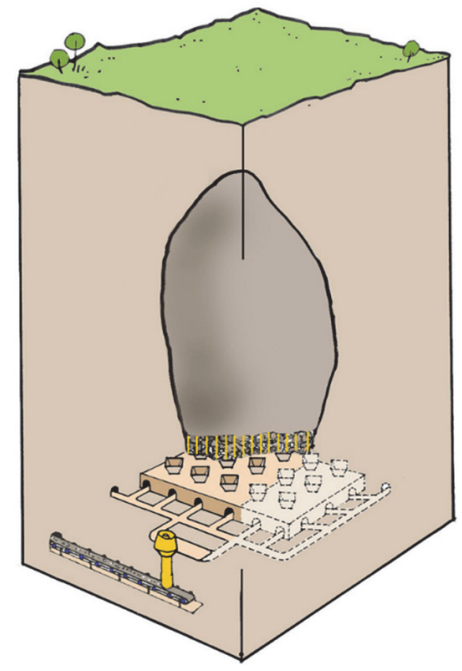

\section{Figure 3 Cave establishment process}

The amount of footprint development in a relatively large contemporary block cave mine can be in the order of hundreds of kilometres (Díaz \& Morales 2008; Fuentes \& Adam 2008; Pascoe et al. 2008; Pasek et al. 2016). The footprint development in a high-stress environment causes sudden redistribution of stresses and, depending on the rock mass characteristics, could generate large mining-induced seismicity. These can result in stress changes in the rock that, under certain conditions (geological faults, lithological contacts), lead to violent failures called rockbursts (Cuello \& Newcombe 2018; Kaiser \& Cai 2012; Ortlepp 1997). Rockbursts often cause severe damage to tunnels, compromise worker safety, and cause interruption to footprint development (Figures 4 and 5). 


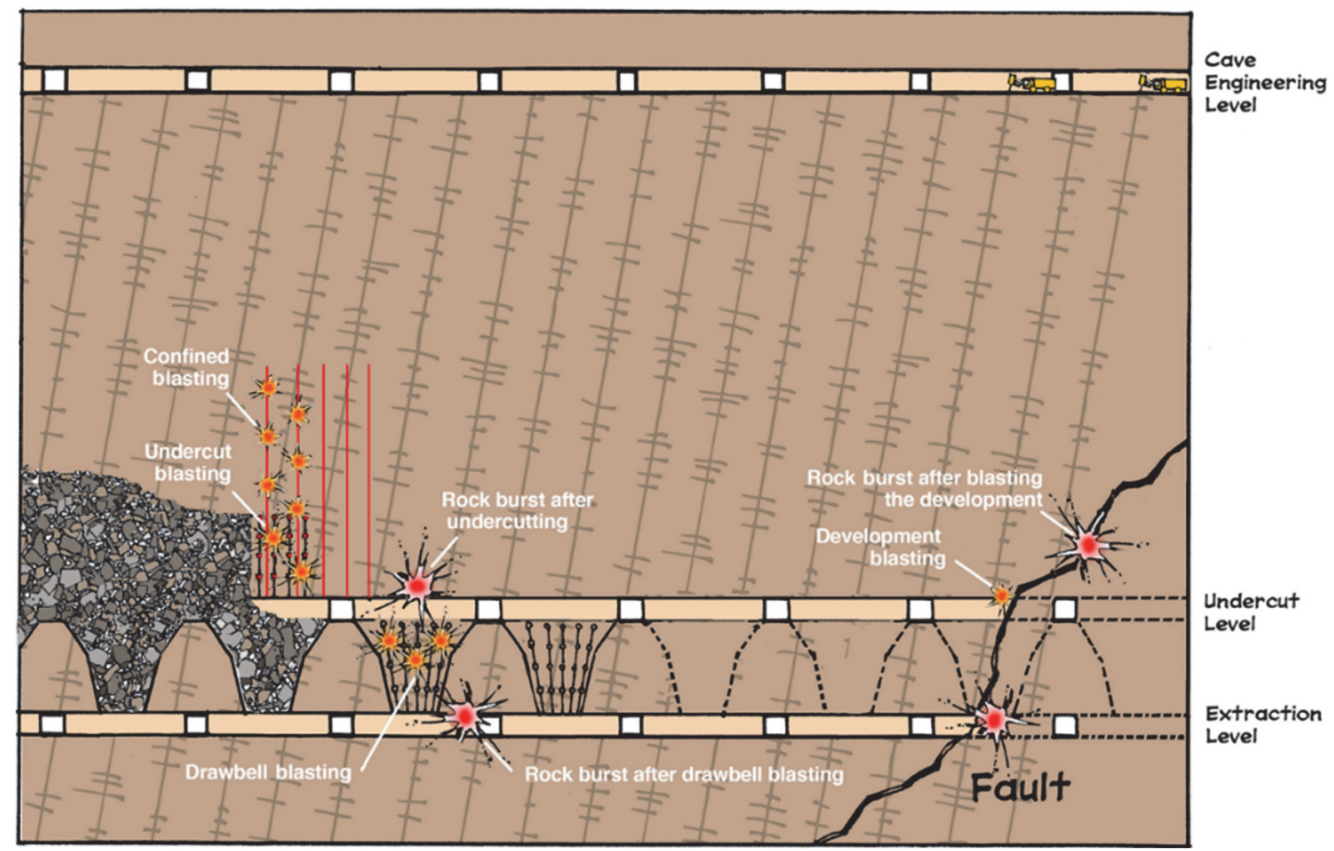

Figure 4 Rockbursts during the cave establishment process
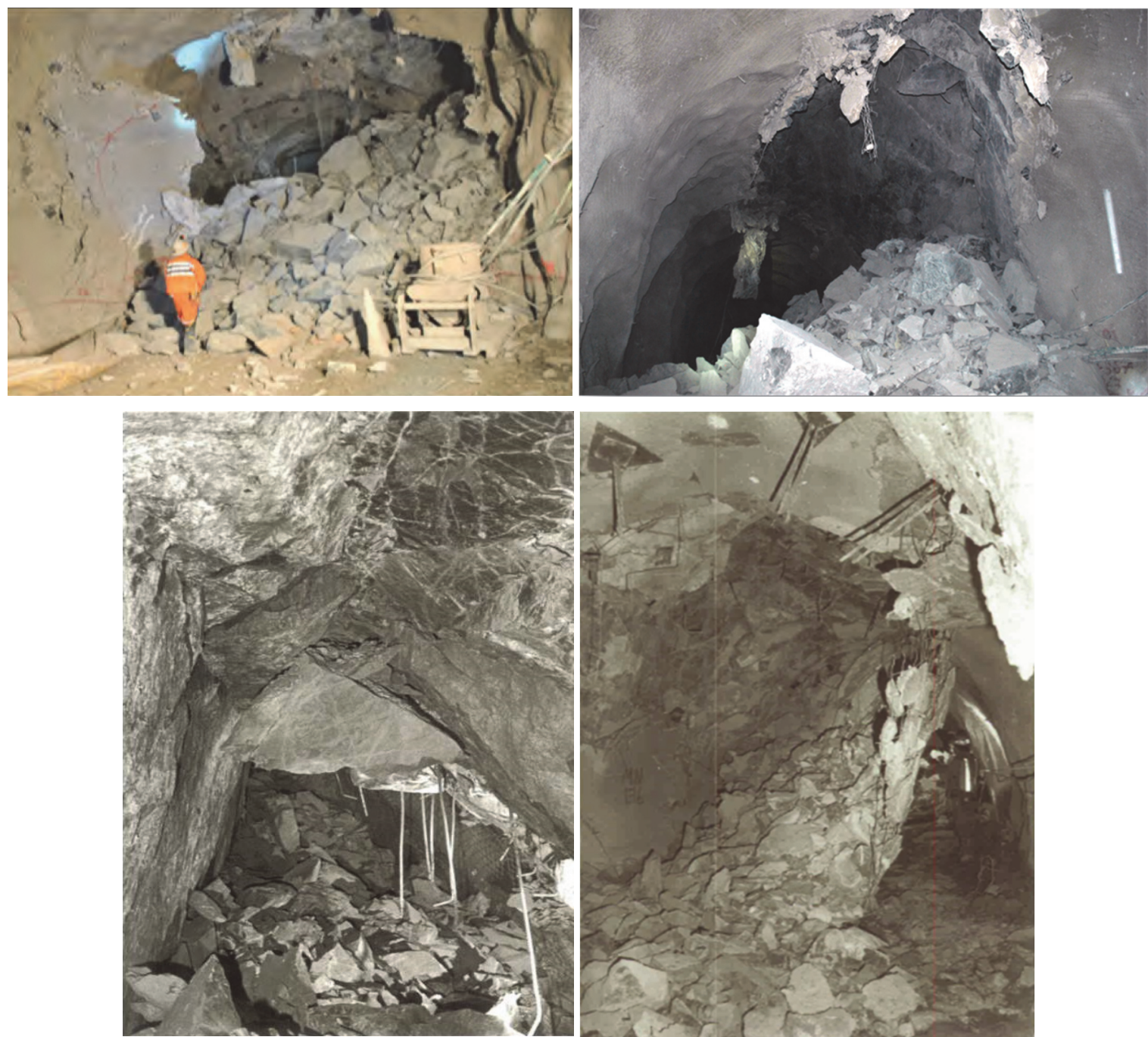

Figure 5 Examples of rockburst damage during the cave establishment process (Rojas \& Balboa 2017) 
To manage this specific hazard, the emerging industry practice is to apply hydrofracturing above and below the volume being developed (Rojas \& Landeros 2017), destressing the rock mass ahead of the development face (Rodríguez et al 2018; Tang 2000), the use of remote drilling and charging, and the application of dynamic ground support (Cuello \& Newcombe 2018; Duan et al. 2015) (Figure 6). This hazard-management strategy serves to change the rock mass characteristics and stress conditions, to remove people from the high-risk development areas, and to contain the ejection of rock due to the rockbursts with magnitude less than two based on Richter scale.

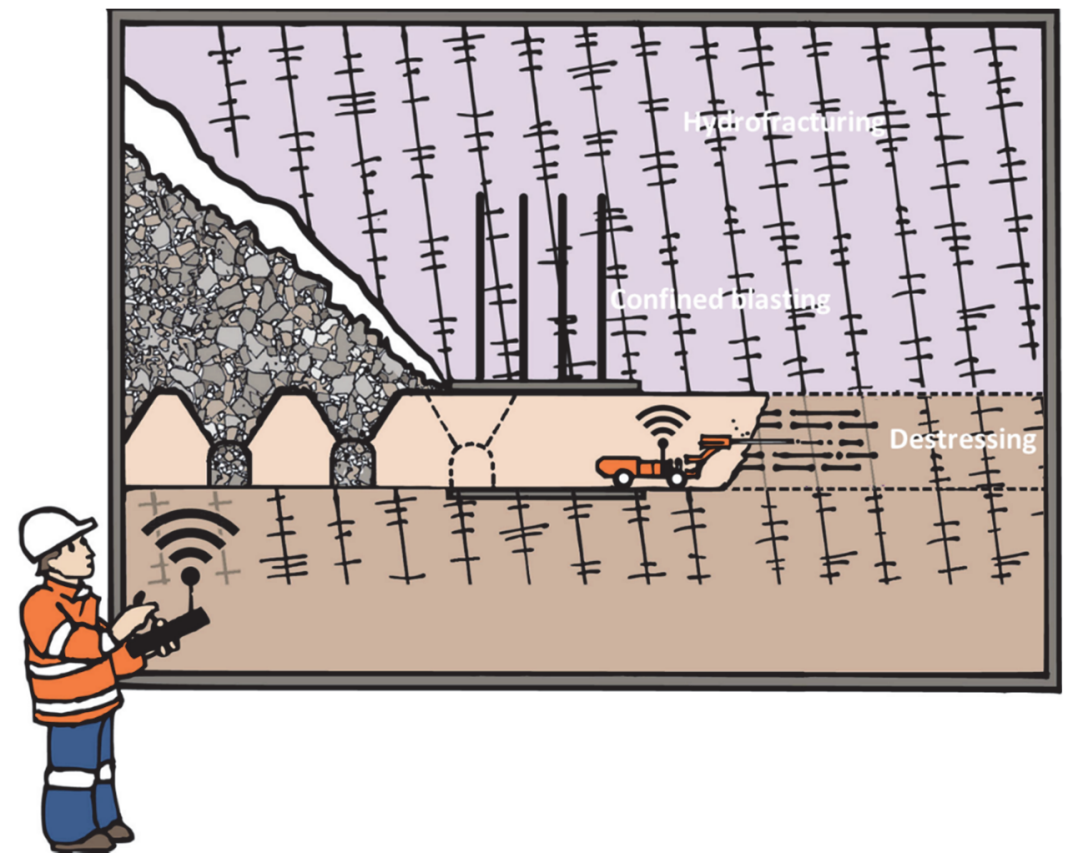

(a)

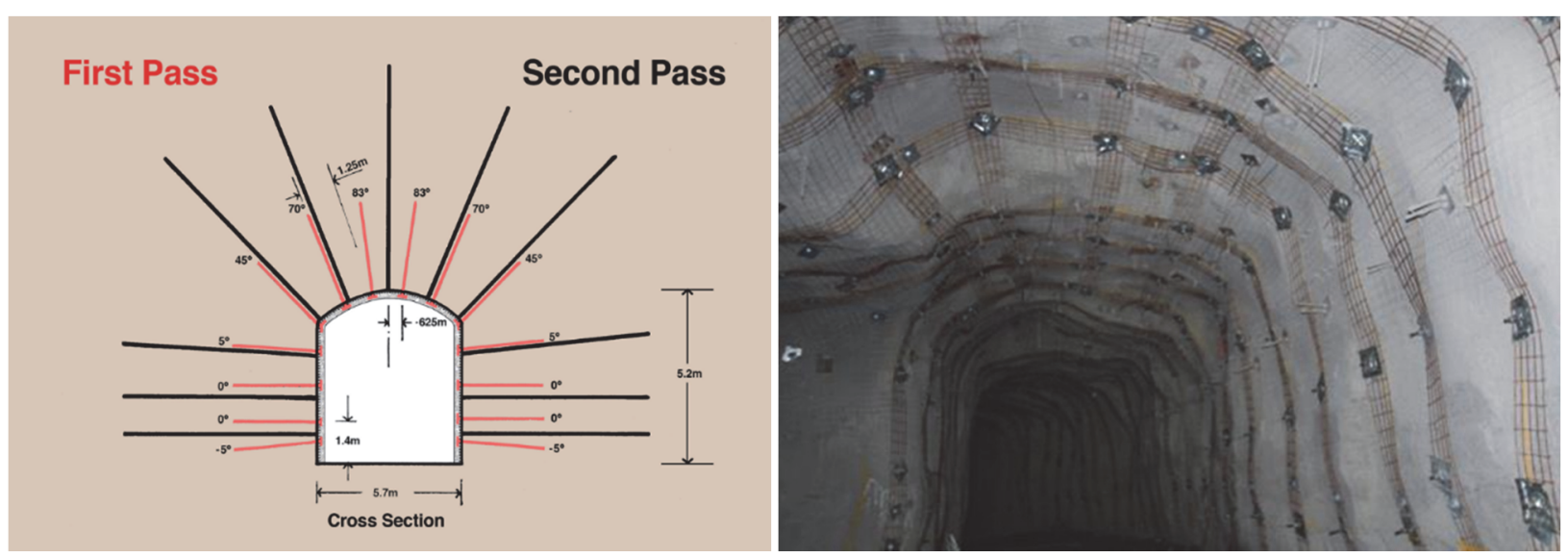

(b)

Figure 6 Rockburst-management strategy. (a) Destressing technique with remote operation equipment; (b) Dynamic ground support (Cuello \& Newcombe 2018)

Similarly, current practices involve rapid or even a single-blast drawbell opening which, under certain conditions, could cause a sudden stress change leading to violent failure of the rock mass (rockburst) surrounding the drawbell (Constanzo et al. 2013; Malovichko et al. 2018; Rojas \& Balboa 2017) (Figure 7). The strategy to manage rockburst due to a single-blast drawbell opening is to hydrofracture the pillar between the undercut and extraction levels before the drawbell opening to reduce the stress concentrations in that area, and to use dynamic ground support (Figure 6). Another emerging practice to manage this hazard is to use remote drilling and charging to improve people safety. 


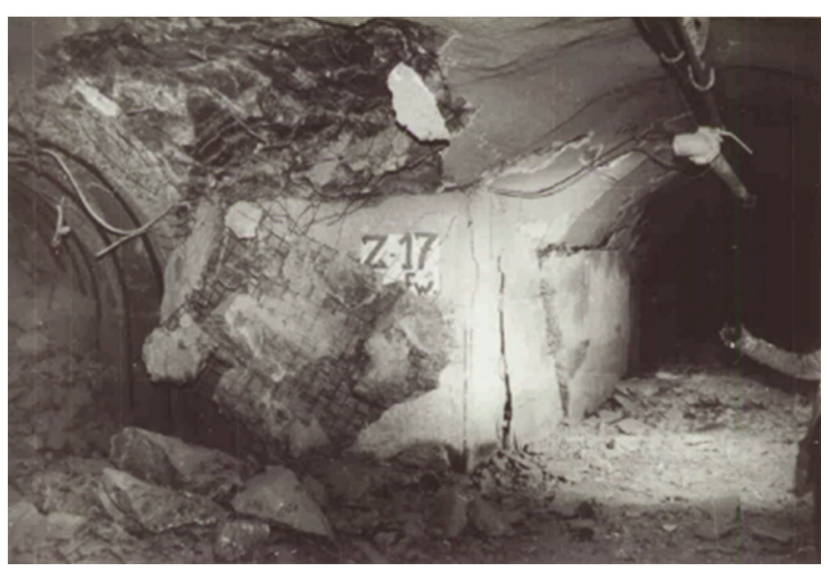

(a)

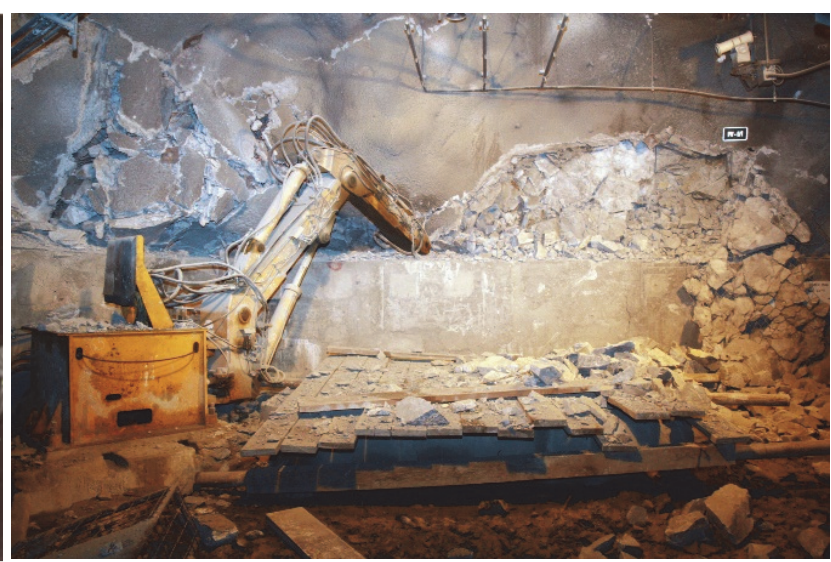

(b)

Figure 7 Examples of rockburst damage experienced after opening a drawbell. (a) Rojas \& Balboa (2017); (b) Malovichko et al. (2018)

Rockburst can also, under certain conditions, be experienced during the undercutting process as undercutting is always carried out in abutment stress environments (Figure 8). This is likely to become more common with increased depth of undercutting. The optimum rockburst management due to undercutting includes the application of hydrofracturing prior to undercutting to modify the rock mass characteristics and reduce the stress concentrations, use of post-undercutting methodology (Pardo \& Rojas 2016), and utilisation of remote drilling and charging. In addition, dynamic ground support (Hadjigeorgiou \& Potvin 2007; Stacey \& Ortlepp 2000) is implemented on the extraction level, especially in the first 50 to $70 \mathrm{~m}$ ahead of the cave front and across the full cave front.

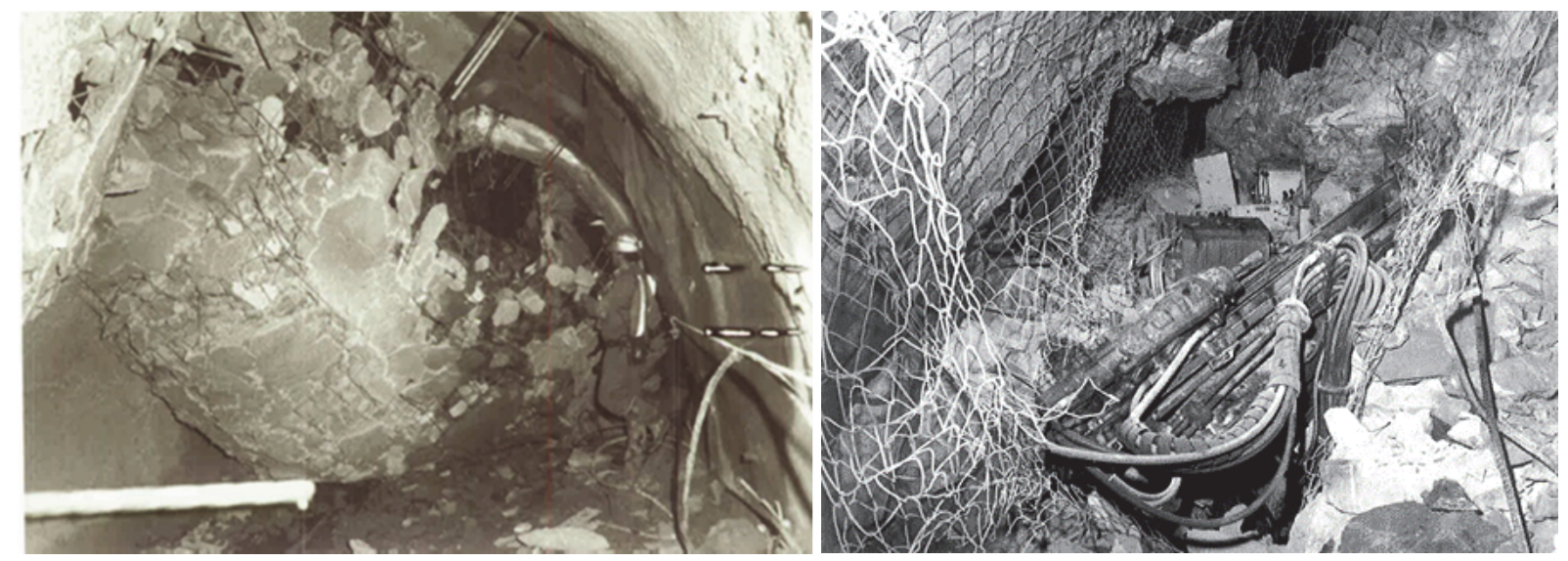

Figure 8 Examples of rockburst damage experienced after undercutting (Rojas \& Balboa 2017)

A global strategy to manage rockburst during cave establishment includes the application of the hydrofracturing technique prior to mining, the implementation of post-undercutting methodology, the use of either remote or autonomous drilling and charging equipment, and the application of dynamic ground support. Collectively, these risk-control measures enable the management of rockbursts, thereby improving underground mining safety and avoiding business interruptions. 


\subsection{Cave propagation}

In the context of this paper, cave propagation includes the onset of caving (cave initiation) and cave propagation to the upper levels or lifts or to the surface (Figure 9).

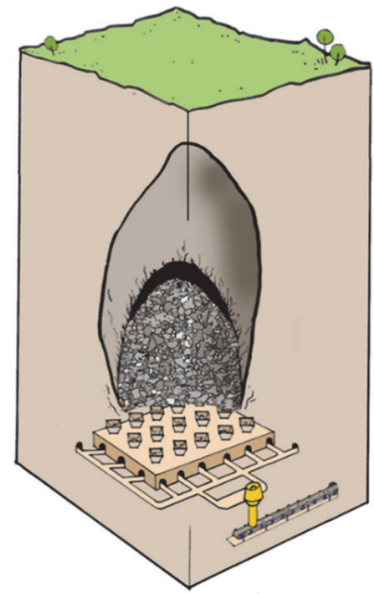

\section{Figure 9 Cave propagation process}

The hazard often associated with cave initiation is rockburst due to the stress changes that occur in the early stages of caving. This hazard is best managed through the application of the hydrofracturing technique or, more recently, intensive preconditioning, which is a combination of hydrofracturing and confined blasting techniques, as shown in Figures 10 and 11 (Catalan et al. 2012a, 2012b, 2012c; Catalan 2015). In the case of hydrofracturing, the optimal practice is to generate artificial fractures along the full block height with more closely fractured spacing at the bottom. In terms of intensive preconditioning, confined blasting is applied only in the bottom section of the block being mined (Sougarret et al. 2004), i.e. the first 100 to $150 \mathrm{~m}$ from the undercut up.

Catalan (2015) defined preconditioning as the implementation of processes to modify the rock mass to enable better control or management of the cave mining process. The term 'modify' is used in this context to mean the process of artificially inducing changes to the rock mass through either hydraulic fracturing or large-scale confined blasting of the rock mass volume to be caved. These processes involve treating or modifying the characteristics of the rock mass using fluid injection or fully confined blasting. Intensive preconditioning is when a combination of hydraulic fracturing and confined blasting is used.

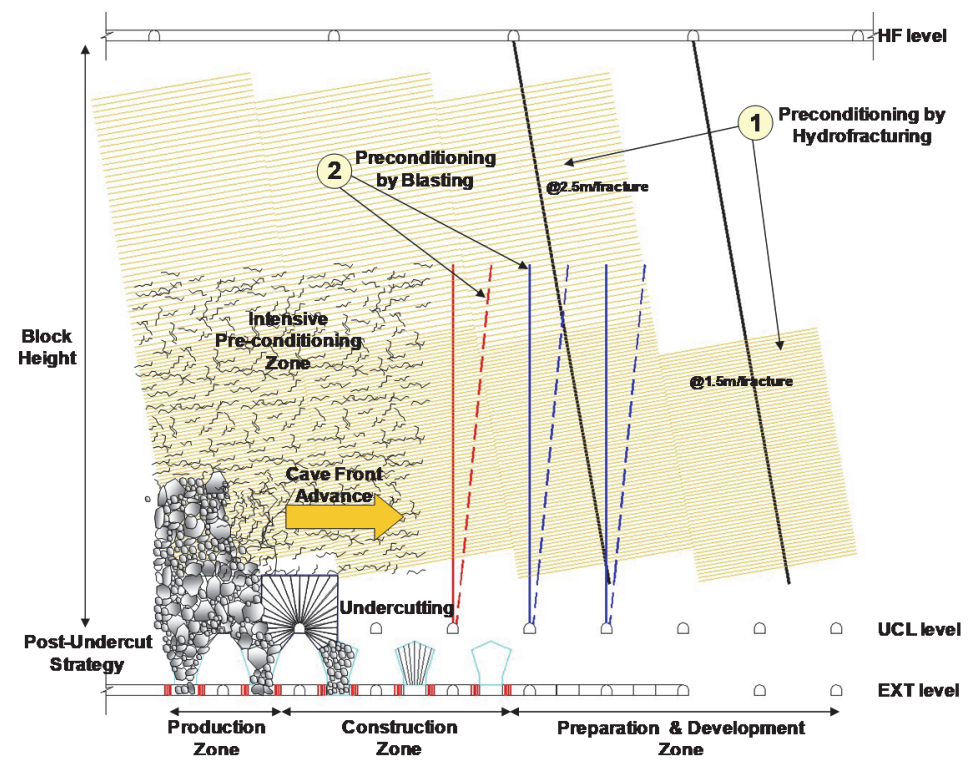

Figure 10 Sequence to implement intensive preconditioning (Catalan et al. 2012c) 


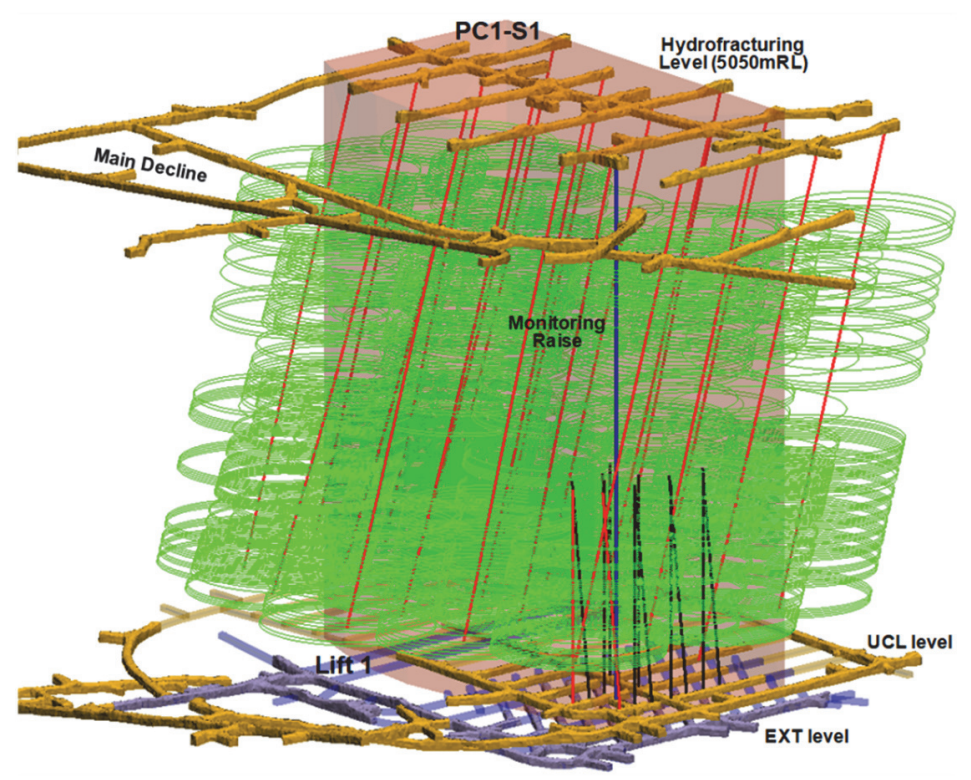

Figure 11 Application of intensive preconditioning at Cadia East PC1 (Catalan et al. 2012c)

During cave propagation, the common hazards are rockbursts and air blasts (Vejrazka 2016). Rockburst is managed the same way as cave initiation using hydrofracturing, as described earlier, and monitoring the cave performance (Carlson \& Golden 2008; Whiteman et al. 2016). Air blast hazards, as defined by Brown (2003, 2007) are "the rapid flow of air through an underground opening following compression of the air in a confined space". In the case of cave mining, there could be instances where the stresses acting on the cave-back are not high enough to break-up the rock mass, thereby arresting cave propagation. This can result in the generation of a large airgap due to the overdrawing of ore in relation to the rate of cave propagation. The sudden failure of the cave-back could trigger an air blast (Figure 12) (Flores 2005).
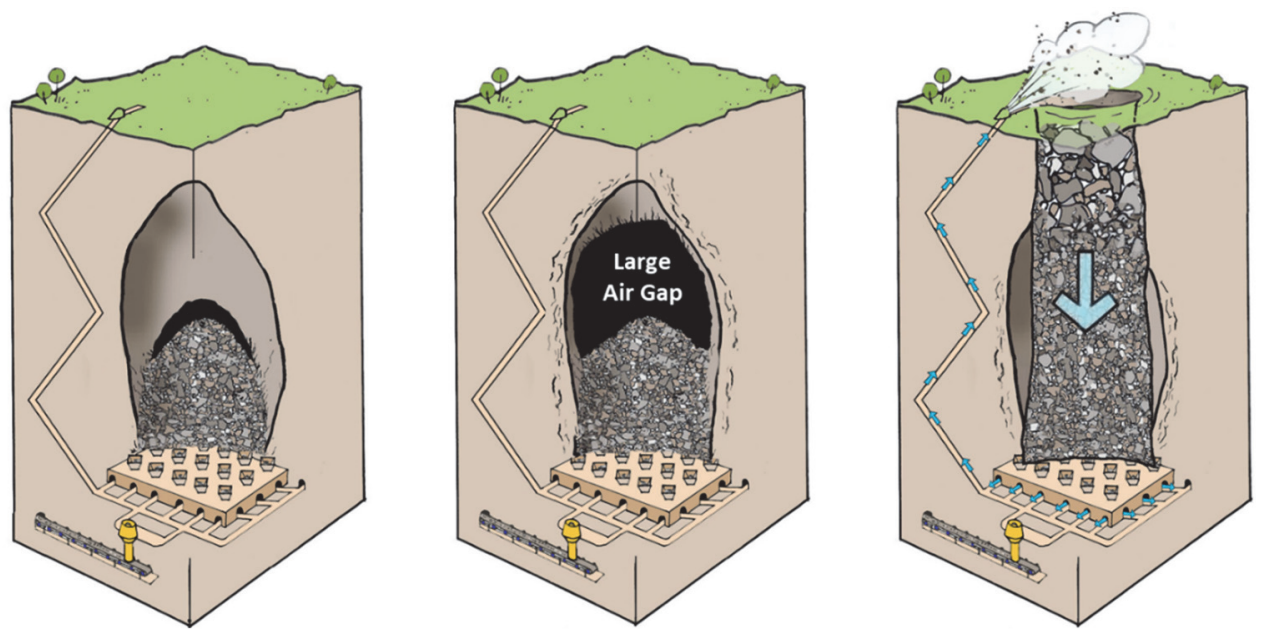

Figure 12 Air blast hazard sequence

Air blast hazard can be managed by the application of hydrofracturing (Catalan et al. 2012c; van As et al. 2000,2004 ) (Figures 10 and 11), to ensure continuous cave propagation and implementation of proper draw control strategies which prevent the formation of large air gaps (Steffen et al. 2016; Wilson et al. 2016).

In summary, the rockburst and air blast hazards associated with cave propagation can be managed by intensive preconditioning (Figure 13). 


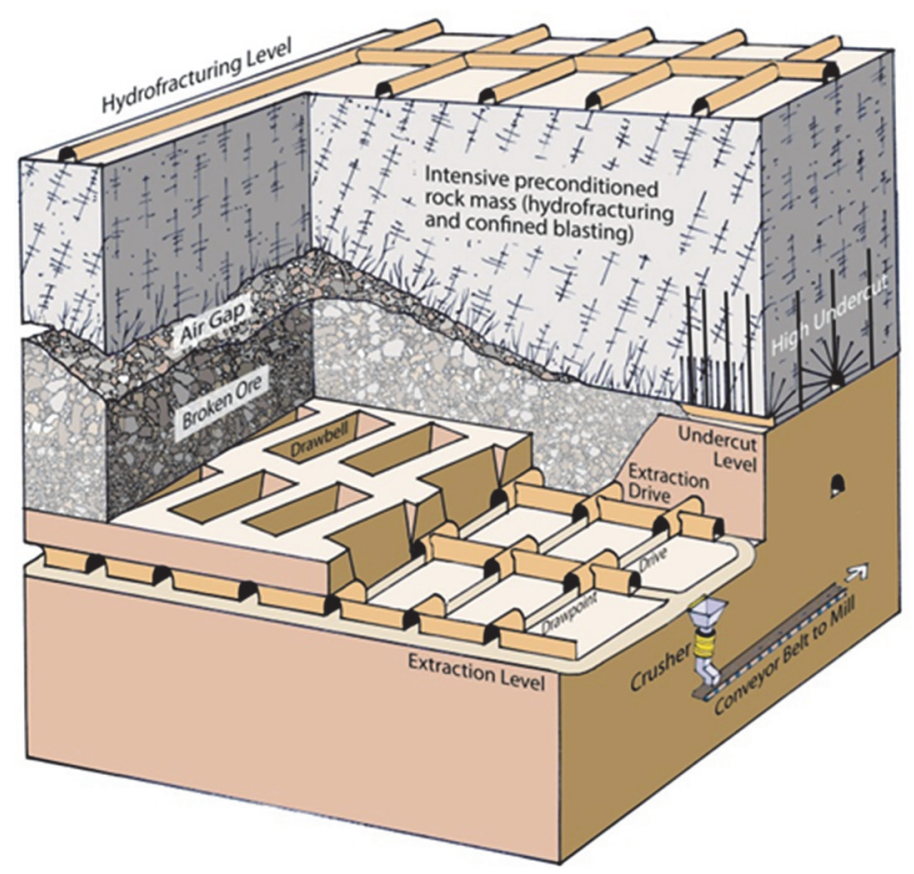

Figure 13 Block caving with intensive preconditioning and post-undercutting (Flores 2014)

\subsection{Cave breakthrough to surface}

The main hazard associated with the breakthrough of the propagating cave to the surface is subsidence (Figure 14). Subsidence which begins once the caving reaches the surface can affect not only the surface infrastructure, but also the location of the main underground accesses and infrastructure. In the literature, subsidence associated with cave mining is also known as 'discontinuous subsidence', as shown in Figures 15 and 16. This is due to large surface displacements and the formation of steps or discontinuities in the surface profile (Flores 2005; Lett et al. 2016a). Existence of any major fault system in the region could exacerbate the impact of subsidence either underground or on surface.
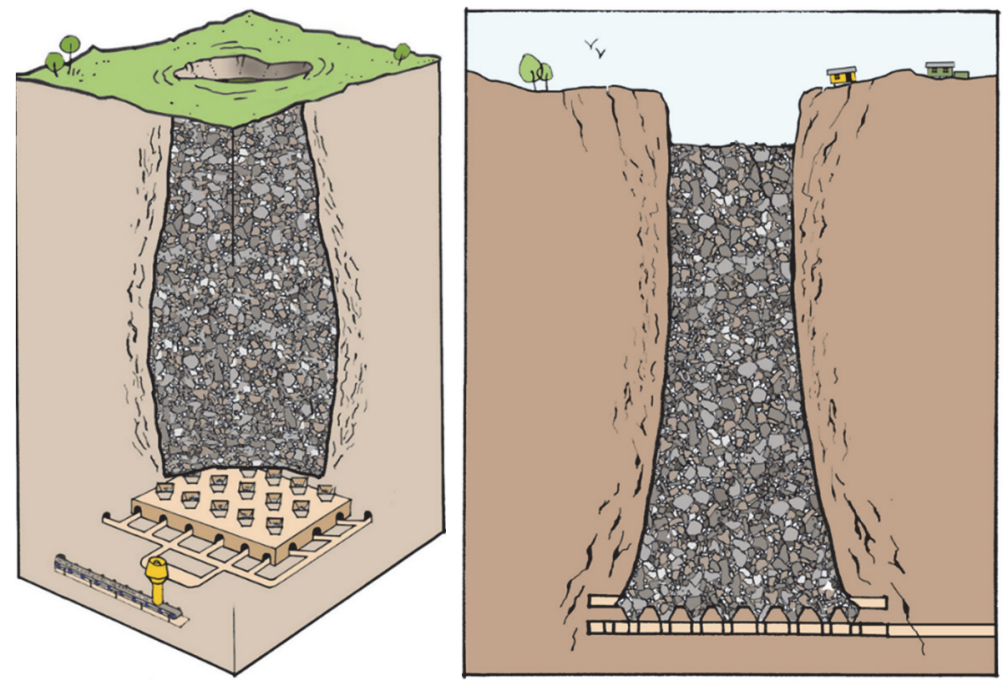

Figure 14 Cave breakthrough process

The corresponding hazard associated with subsidence is the sudden damage to surface and/or underground infrastructure (Pretorius \& Ngidi 2008; Sainsbury et al. 2016). The current tools used by the caving industry to manage subsidence hazard are hydrofracturing of the crown pillar (Lett et al. 2016b; Lowther et al. 2016), numerical modelling, and monitoring systems such as prims, extensometers and open holes. The prediction of subsidence envelope in terms of time and geometry unfortunately remains poor. Significant effort is still 
required to improve the prediction of subsidence. Fortunately, there has been major development in terms of access to more precise monitoring systems such as lidar (Espinoza \& Landeros 2014) and satellite (InSAR) to help with the management of subsidence (Espinoza et al. 2014).
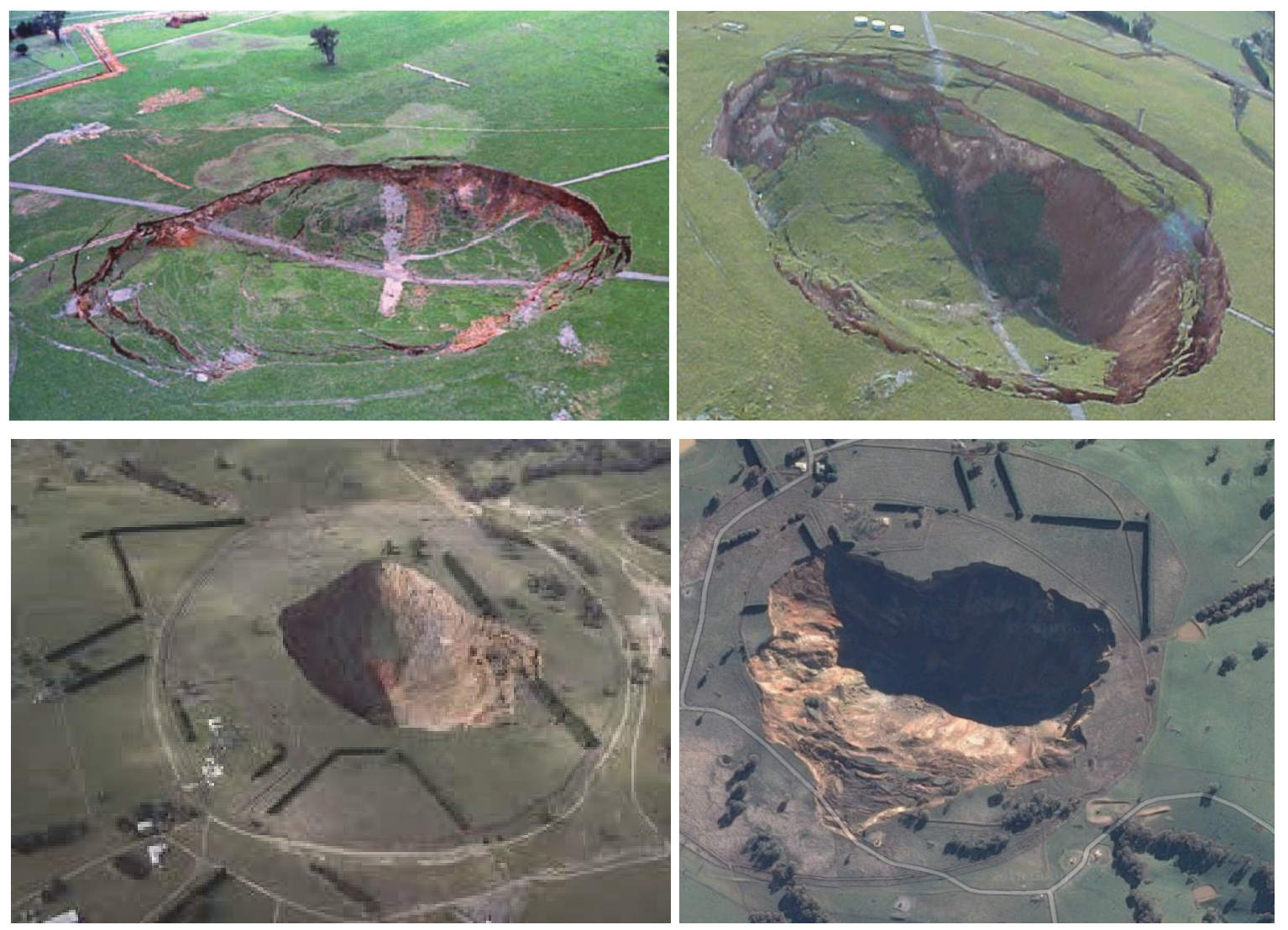

Figure 15 Surface subsidence at Newcrest Mining Limited's Ridgeway and Ridgeway Deeps

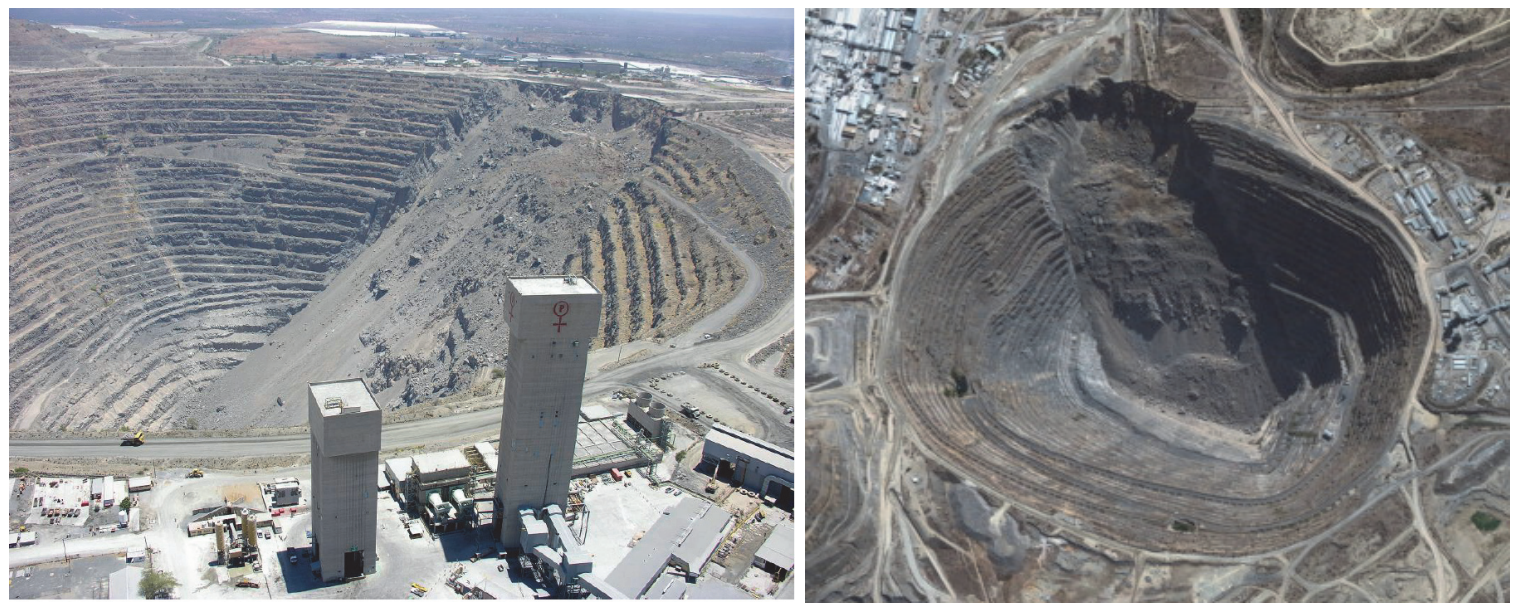

Figure 16 Palabora subsidence during cave breakthrough to surface (Pretorius \& Ngidi 2008) 


\subsection{Cave steady state production}

Steady state production is a process which follows the breakthrough of the cave column to surface (Figure 17). This process causes the readjustment of stresses around the cave due to high production rates. This readjustment of stresses can cause rockbursts due to fault slip of major geological faults in the cave vicinity. Management of this hazard is by the application of hydrofracturing around the major faults and monitoring of mining-induced seismicity.
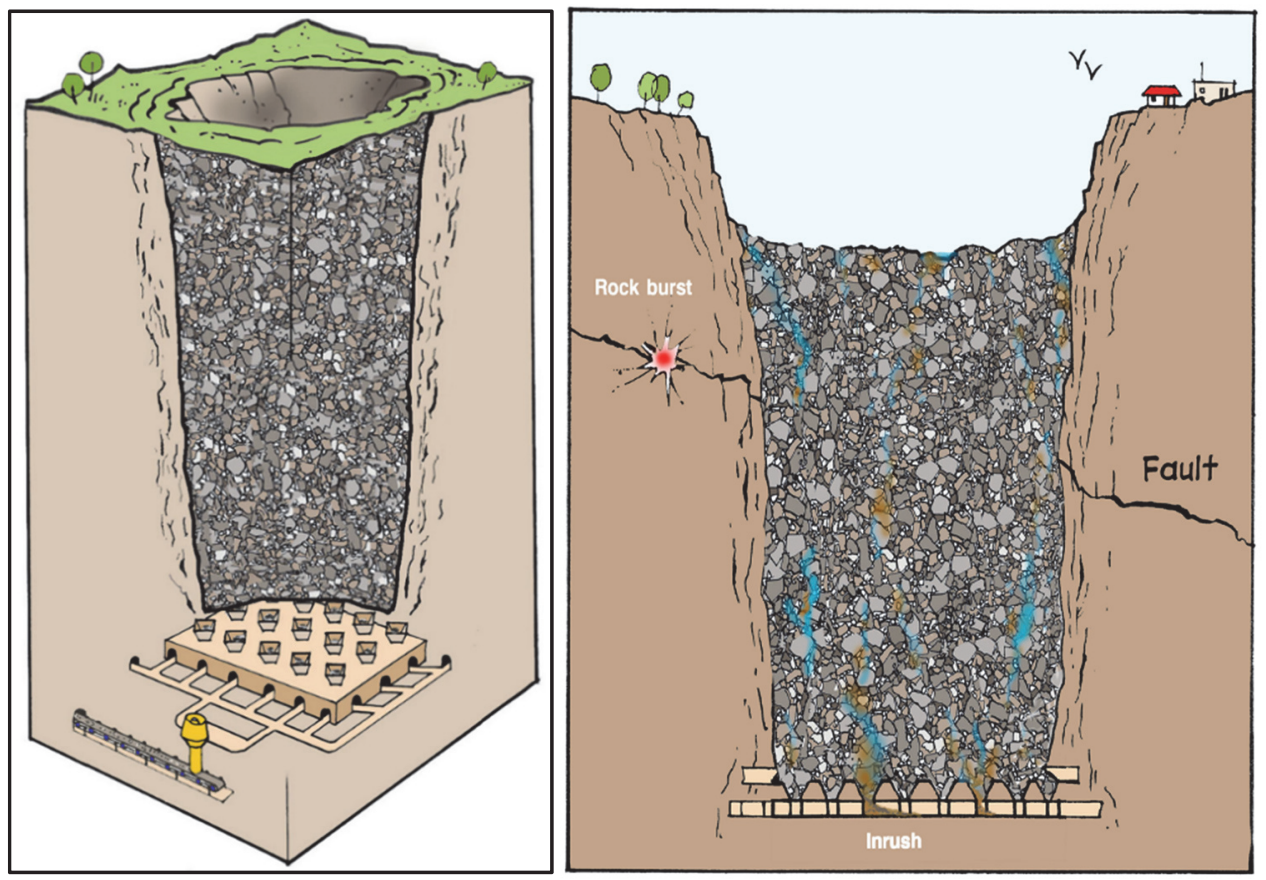

Figure 17 Cave steady state production process

Inrushes are another hazard associated with the steady state production process, and they include water inflows, dry rushes and mudrushes (Figures 18 and 19). Water inflows are "water gushes from the drawpoint or other underground opening due to accumulation of water in the muckpile over time". Dry rush is a "sudden inflow of dry and fine material from the drawpoint" (Long et al. 2017). Mudrush is a sudden inflow of mud from a drawpoint or other underground opening. They may cause harm to people and equipment, production delays, dilution and mine closure.

These inflows are random and can be triggered by a number of events such as drawing, induced seismicity, and secondary breakage activities at the drawpoint or orepass (e.g. blasting and vibrations). To manage these hazards requires access to a good hydrogeological model of the caving system, implementation of an appropriate water-management system and remote, semi-autonomous or autonomous operations (Hubert et al. 2000; Pratt 2016; Revuelta et al. 2008; Samosir et al. 2008; Wicaksono et al. 2012). Other critical control measures currently used in the caving industry are backfilling of the subsidence crater with compacted clay, bunding of the drawpoint, and reducing the aperture of the drawpoint (Figure 20). 

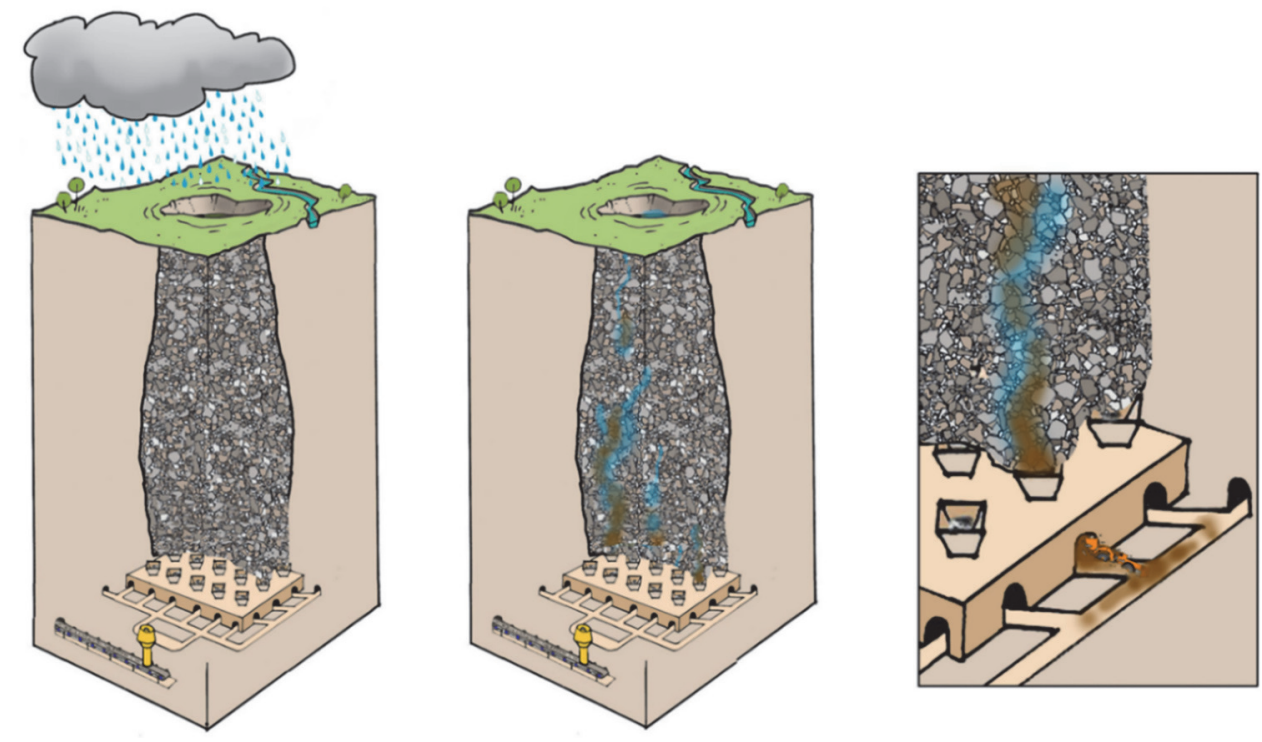

Figure 18 Inrush hazard sequence

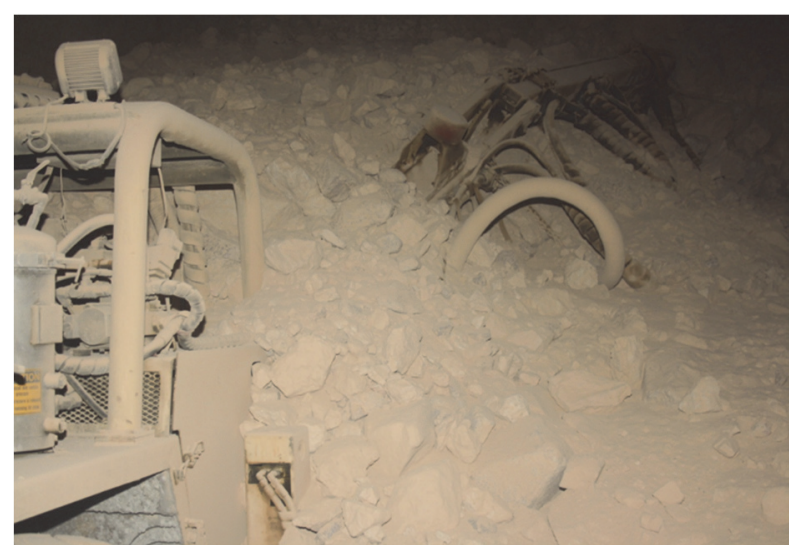

(a)

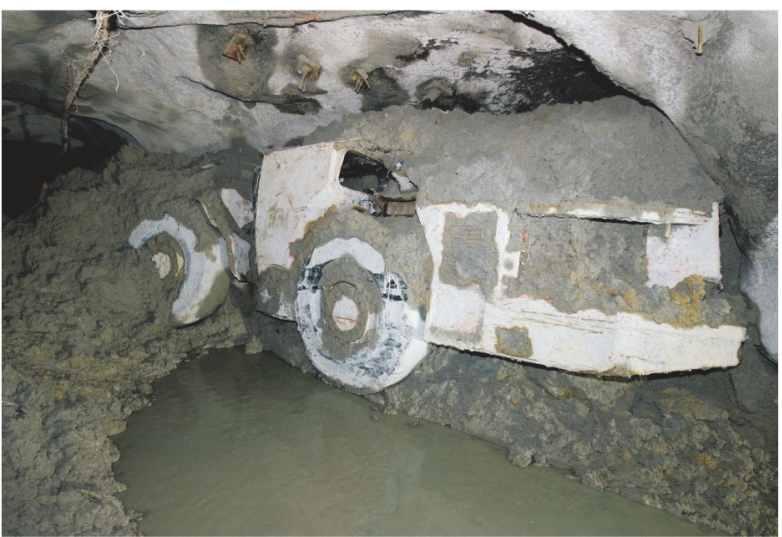

(c)

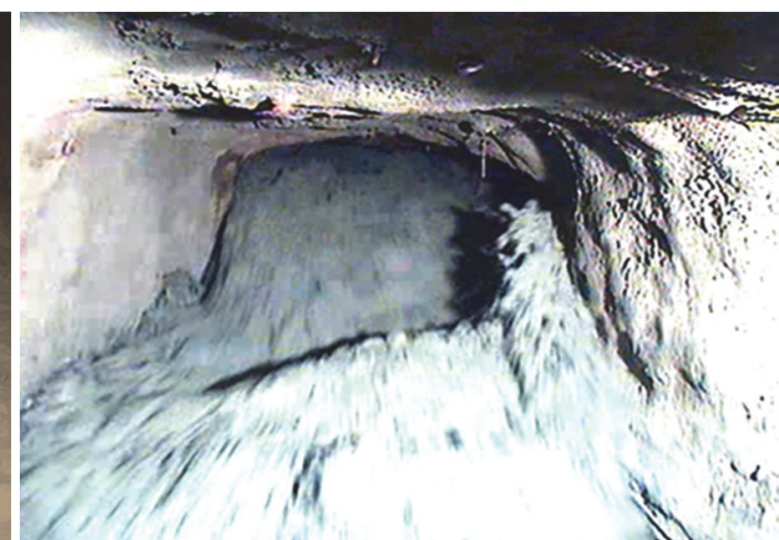

(b)

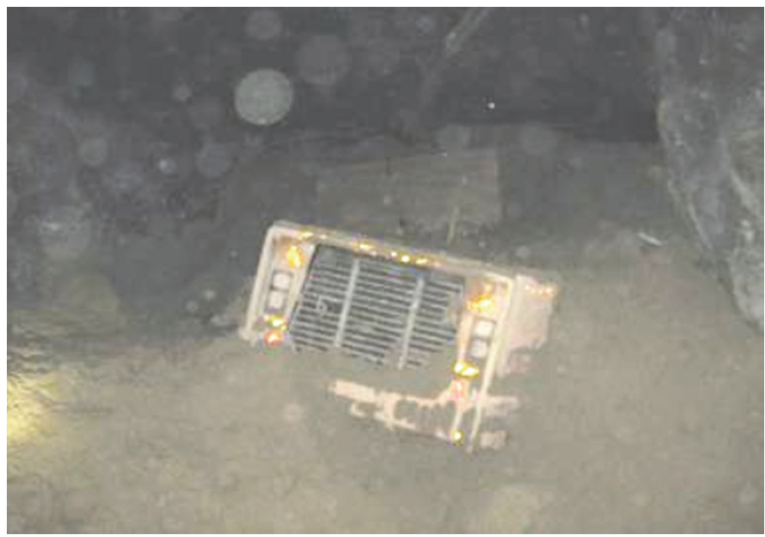

(d)

Figure 19 Inrush hazard during cave steady state production process. (a) Dry inrush (Long et al. 2017); (b) Water inrush (Jakubec et al. 2012); (c) Mudrush (Revuelta et al. 2008); (d) Mudrush (Widijanto 2012) 


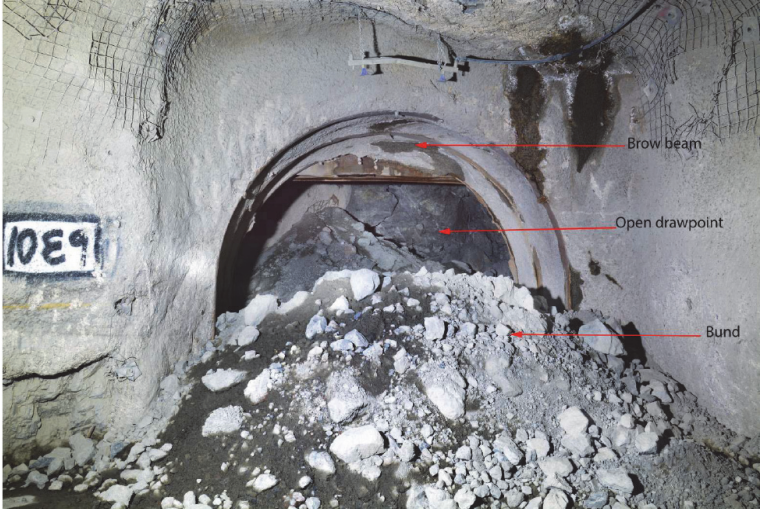

(a)

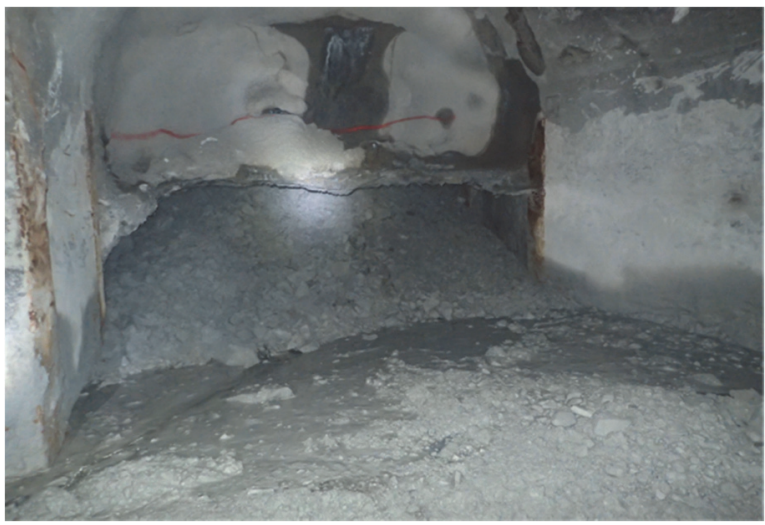

(c)

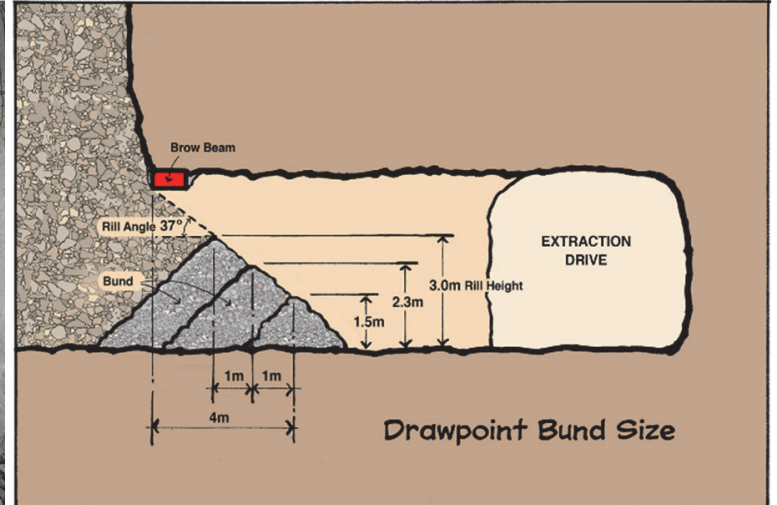

(b)

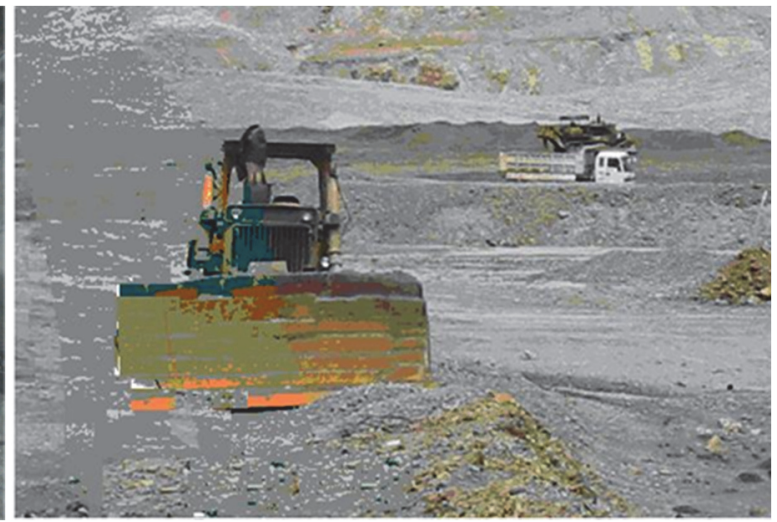

(d)

Figure 20 Other critical control measures for inrushes. (a) Bund at the drawpoint (Department of Industry 2017); (b) Bund design (Department of Industry 2017); (c) Drawpoint with reduced aperture (PT Freeport Indonesia); (d) Backfilling the subsidence crater at Padcal mine (Philexmonitor n.d.)

\section{Conclusion}

The major hazards in cave mining, as discussed in this paper, are rockbursts, air blasts, subsidence and inrushes. These hazards are often experienced during cave establishment, cave propagation, cave breakthrough and cave steady state production processes. The global management of these hazards is to focus on improving safety and reducing business interruptions. The latter is managed mainly through the application of intensive preconditioning in combination with post-undercutting, application of dynamic ground support, utilisation of remote or semi-autonomous operations, and a reliable monitoring system.

Cave mining will continue being an attractive method for quite some time. This is provided that it remains a method with low cost and high productivity. However, the major hazards associated with cave mining will be more severe at depth greater than 1,400 $\mathrm{m}$ from surface. These envisaged future challenges, which are significantly outside past and/or present experience, dictate that significant changes to current practices to manage the major caving hazards are required. These major hazards are considered common challenges for the majority, if not all operating block caves, and demand a collective industry solution.

In order to be proactive, in terms of managing these more severe hazards at depth, the caving industry should introduce:

- Ultra-conditioning to reduce not only the magnitude of the large induced seismicity, but the potential for air blasts. Ultra-conditioning, in this case, is the combination of hydrofracturing and confined blasting techniques along the entire block height. This also includes hydrofracturing around the footprint where the infrastructure is located. 
- New mine layouts to reduce the lateral and vertical development to decrease the capital and timing required to establish the footprint.

- New autonomous drilling and charging technology to remove people from high-stress, risky areas. Mechanical excavation is another option to establish the footprint and accesses.

- A fully autonomous material handling system from the drawpoint to the crusher and then to the mill.

- New ground support elements with higher dynamic loading capacity.

- New active monitoring systems should be developed to help understand cave performance and proactively make appropriate operational decisions to improve safety and reduce business interruptions.

\section{Acknowledgement}

The author especially acknowledges Professor Gideon Chitombo of the Sustainable Minerals Institute, The University of Queensland, Australia for his kind advice on the preparation of the paper, and Eduardo Rojas, David Cuello, Tim Casten and Alex Campbell for having provided him with material used in assembling the paper. He also thanks Associate Professor Johan Wesseloo of the Australian Centre for Geomechanics for inviting me to be one of the keynote speakers for this conference. Finally, the author is also immensely grateful to Jock Macneish and Robert Black of Strategic Images who have contributed with the illustrations for this paper. The permission of Newcrest Mining Limited to publish this paper is gratefully acknowledged.

\section{References}

Brown, ET 2003, Block Caving Geomechanics, JKMRC Monograph Series on Mining and Mineral Processing 3, Julius Kruttschnitt Mineral Research Centre, Indooroopilly.

Brown, ET 2007, Block Caving Geomechanics, 2nd edn, Julius Kruttschnitt Mineral Research Centre, Indooroopilly.

Brown, ET \& Chitombo, GP 2007, Underground Mass Mining by Caving: The way of the Future, Sustainable Minerals Institute, St Lucia, and The University of Queensland, Indooroopilly.

Brown, ET 2012, 'Progress and challenges in some areas of deep mining', in Y Potvin (ed.), Proceedings of the Sixth International Seminar on Deep and High Stress Mining, Australian Centre for Geomechanics, Perth, pp. 1-24.

Carlson, G \& Golden, R 2008, 'Initiation, growth, monitoring and management of the 7210 cave at Henderson Mine - A case study', in $\mathrm{H}$ Schunnesson \& E Nordlund (eds), Proceedings the 5th International Conference and Exhibition on Mass Mining, Luleå University of Technology, Luleå, pp. 97-106.

Catalan, A, Onederra, I \& Chitombo, G 2012a, 'A proposed methodology for evaluation of the preconditioning by blasting at the Cadia East panel cave mine', Proceedings of the 6th International Conference and Exhibition on Mass Mining, Canadian Institute of Mining, Metallurgy and Petroleum, Westmount.

Catalan, A, Dunstan, G, Morgan, M, Green, S, Jorquera, M \& Thornhill, T 2012b, 'An intensive preconditioning methodology developed for the Cadia East panel cave project, NSW, Australia', Proceedings of the 6th International Conference and Exhibition on Mass Mining, Canadian Institute of Mining, Metallurgy and Petroleum, Westmount.

Catalan, A, Dunstan, G, Morgan, M, Green, S, Jorquera, S, Thornhill, T, Onederra, I \& Chitombo, G 2012c, 'How can an intensive preconditioning concept be implemented at mass mining method? Application to Cadia East panel caving project', Proceedings of the 46th US Rock Mechanics/Geomechanics Symposium American Rock Mechanics Association, Alexandria.

Catalan, A 2015, Implementation and Assessment of Intensive Preconditioning for Cave Mining Applications, PhD thesis, The University of Queensland, Brisbane.

Constanzo, H, Lopez, S \& Videla, J 2013, 'State of the art in cave mining', Proceedings of the Third International Seminar on Mine Planning, pp. 145-153.

Cuello, D \& Newcombe, G 2018, 'Key geotechnical knowledge and practical mine planning guidelines in deep, high-stress, hard rock conditions for block and panel cave mining', in Y Potvin \& J Jakubec (eds), Proceedings of the Fourth International Symposium on Block and Sublevel Caving, Australian Centre for Geomechanics, Perth, pp. 17-36.

Department of Industry 2017, Investigation Report - Report into the Death of Lee Peters at the Ridgeway Mine, Cadia, NSW on 6 September 2015, Department of Industry, Resources Regulator, Government of New South Wales, viewed 6 March 2019, https://www.resourcesregulator.nsw.gov.au/_data/assets/pdf_file/0009/701478/investigation-report-ridgeway-mine.pdf

Díaz, G \& Morales, E 2008, 'Tunnelling and construction for 140.000 tonnes per day - El Teniente mine - Codelco Chile', in H Schunnesson \& E Nordlund (eds), Proceedings the 5th International Conference and Exhibition on Mass Mining, Luleå University of Technology, Luleå, pp. 83-96.

Duan, W, Wesseloo, J \& Potvin, Y 2015, 'Evaluation of the adjusted rockburst damage potential method for dynamic ground support selection in extreme rockburst conditions', in Y Potvin (ed.), Proceedings of the International Seminar on Design Methods in Underground Mining, Australian Centre for Geomechanics, Perth, pp. 399-418. 
Espinoza, A \& Landeros, P 2014, 'Implementation of LiDAR technology to evaluate deformation field induced by panel caving exploitation, Codelco Chile El Teniente Division', in R Castro (ed.), Proceedings of the Third International Symposium on Block and Sublevel Caving, Universidad de Chile, Santiago, pp. 394-402.

Espinoza, AE, Mora, O \& Sánchez, F 2014, 'Application of InSAR technique for monitoring and control of surface subsidence generated by underground mining', in R Castro (ed.), Proceedings of the Third International Symposium on Block and Sublevel Caving, Universidad de Chile, Santiago, pp. 603-610.

Flores, G 2005, Rock Mass Response to the Transition from Open Pit to Underground Cave Mining, PhD thesis, The University of Queensland, Brisbane.

Flores, G, Karzulovic, A \& Brown, ET 2004, 'Current practices and trends in cave mining', in A Karzulovic \& M Alfaro (eds), Proceedings of MassMin 2004, Chilean Engineering Institute, Santiago, pp. 83-90.

Flores, G 2014, 'Future challenges and why cave mining must change', in R Castro (ed.), Proceedings of the Third International Symposium on Block and Sublevel Caving, Universidad de Chile, Santiago, pp. 23-52.

Fuentes, S \& Adam, E 2008, 'Chuquicamata underground mine - project status update', in H Schunnesson \& E Nordlund (eds), Proceedings the 5th International Conference and Exhibition on Mass Mining, Luleå University of Technology, Luleå, pp. 461-470.

Hadjigeorgiou, J \& Potvin, Y 2007, 'Overview of dynamic testing of ground support', in Y Potvin (ed.), Proceedings of the Fourth International Seminar on Deep and High Stress Mining, Australian Centre for Geomechanics, Perth, pp. 349-371.

Hubert, G, Dirdjosuwondo, S, Plalsance, R \& Thomas, L 2000, 'Tele-operation at Freeport to reduce wet muck hazards', in G Chitombo (ed.), Proceedings of MassMin 2000, The Australasian Institute of Mining and Metallurgy, Melbourne, pp. 173-180.

Jakubec, J, Clayton, R \& Guest, AR 2012, 'Mudrush risk evaluation', Proceedings of the 6th International Conference and Exhibition on Mass Mining, Canadian Institute of Mining, Metallurgy and Petroleum, Westmount.

Kaiser, P \& Cai, M 2012, 'Design of rock support system under rockburst condition', Journal of Rock Mechanics and Geotechnical Engineering, vol. 4, no. 3, pp. 215-227.

Lett, J, Brunton, I, Capes, G, Jäger, A, Mobilio, B, Rachocki, J, Sharrock, G \& Secheny, M 2016a, 'Undercutting to surface breakthrough - Cadia East panel cave (stage 1)', in C Carr \& G Chitombo (eds), Proceedings of the Seventh International Conference and Exhibition on Mass Mining, The Australasian Institute of Mining and Metallurgy, Melbourne, pp. 65-81.

Lett, J, Jäger, A, Thornhill, T, Rachocki, J \& Mobilio, B 2016b, 'Geotechnical challenges in cave monitoring - a modern approach', in C Carr \& G Chitombo (eds), Proceedings of the Seventh International Conference and Exhibition on Mass Mining, The Australasian Institute of Mining and Metallurgy, Melbourne, pp. 202-216.

Long, S, Carnovale, D \& Louwrens, L 2017, 'Mt Wright - managing unique risks', Proceedings of the 13th Aus/MM Underground Operators Conference, The Australasian Institute of Mining and Metallurgy, Melbourne, pp. 295-304.

Lowther, R, Olivier, L, Lett, J \& Brunton, I 2016, 'Implementation of a surface-based hydraulic fracturing program to successfully propagate a large cave through hard competent near-surface rock masses to achieve breakthrough', in C Carr \& G Chitombo (eds), Proceedings of the Seventh International Conference and Exhibition on Mass Mining, The Australasian Institute of Mining and Metallurgy, Melbourne, pp. 83-96.

Malovichko, D, Cuello, D \& Rojas, E 2018, 'Analysis of damaging seismic event on 24 December 2011 in the Pilar Norte sector of El Teniente mine', in Y Potvin \& J Jakubec (eds), Proceedings of the Fourth International Symposium on Block and Sublevel Caving, Australian Centre for Geomechanics, Perth, pp. 637-650.

Ortlepp, WD 1997, Rock Fracture and Rockbursts: an Illustrative Study, South African Institute of Mining and Metallurgy, Johannesburg.

Pardo, C \& Rojas, E 2016, 'Selection of exploitation method based on the experience of hydraulic fracture techniques at the EI Teniente mine', in C Carr \& G Chitombo (Eds), Proceedings of the Seventh International Conference and Exhibition on Mass Mining, The Australasian Institute of Mining and Metallurgy, Melbourne, pp. 97-104.

Pascoe, C, Oddie, M \& Edgar, I 2008, 'Panel caving at the Resolution copper project', in H Schunnesson \& E Nordlund (eds), Proceedings the 5th International Conference and Exhibition on Mass Mining, Luleå University of Technology, Luleå, pp. 35-42.

Pasek, I, Firdausi, H \& Chenier, T 2016, 'Development of the ore handling system at the Grasberg block cave mine, Indonesia', Proceedings of the Seventh International Conference and Exhibition on Mass Mining, The Australasian Institute of Mining and Metallurgy, Melbourn, pp. 599-607.

Philexmonitor n.d., Geology, Reserves, and Mining Method/Processing, Philexmonitor, http://philexmonitor.synthasite.com/ resources/05chap4.pdf

Pratt, A 2016, 'Autonomous haulage systems in underground mining - what is required for success?', in C Carr \& G Chitombo (eds), Proceedings of the Seventh International Conference and Exhibition on Mass Mining, The Australasian Institute of Mining and Metallurgy, Melbourne, pp. 35-52.

Pretorius, D \& Ngidi, S 2008, 'Cave management ensuring optimal life of mine at Palabora', in H Schunnesson \& E Nordlund (eds), Proceedings the 5th International Conference and Exhibition on Mass Mining, Luleå University of Technology, Luleå, pp. 63-71.

Revuelta, J, Reyes, F \& Pozo, R 2008, 'El Teniente new mine level project', Proceedings of the First International Future Mining Conference and Exhibition 2008, The Australasian Institute of Mining and Metallurgy, Melbourne, pp 39-50.

Rodríguez, W, Sánchez, J, Castro, D, Troncoso, C \& Arce, J 2018, 'Aplicación de de-stress blasting en desarrollo de túneles en ambiente de esfuerzos altos', Proceedings of UMining 2018, pp. 472-482, in Spanish.

Rojas, E \& Balboa, S 2017, 'Management of seismic hazard in high stress condition, El Teniente mine', in JA Vallejos (ed.), Proceedings of the 9th International Symposium on Rockbursts and Seismicity in Mines, University of Chile, Santiago, pp. 264-273. 
Rojas, E \& Landeros, P 2017, 'Hydraulic fracturing applied to tunnel development at El Teniente mine', in JA Vallejos (ed.), Proceedings of the 9th International Symposium on Rockbursts and Seismicity in Mines, University of Chile, Santiago, pp. 236-242.

Sainsbury, D, Sainsbury, B, Paetzold, H, Lourens, P \& Vakili, A 2016, 'Caving-induced subsidence behaviour of Lift 1 at the Palabora block cave mine', in C Carr \& G Chitombo (eds), Proceedings of the Seventh International Conference and Exhibition on Mass Mining, The Australasian Institute of Mining and Metallurgy, Melbourne, pp. 415-426.

Samosir, E, Basuni, J, Widijanto, E \& Syaifullah, T 2008, 'The management of wet muck at PT Freeport Indonesia's Deep Ore Zone mine', in H Schunnesson \& E Nordlund (eds), Proceedings the 5th International Conference and Exhibition on Mass Mining, Luleå University of Technology, Luleå, pp. 323-332.

Sougarret, J, Quiñones, L, Morales, R \& Apablaza, R 2004, 'New vision in caving mining in Andina Division, Codelco Chile', in A Karzulovic \& M Alfaro (eds), Proceedings of MassMin 2004, Chilean Engineering Institute, Santiago, pp. 542-546.

Stacey, TR \& Ortlepp, DW 2000, 'Support appropriate for dynamic loading and large static loading in block cave mining openings', in G Chitombo (ed.), Proceedings of MassMin 2000, The Australasian Institute of Mining and Metallurgy, Melbourne, pp. 783-790.

Steffen, S, Poulsen, J, van As, A, Talu, S, Watt, G \& Ooi, J 2016, 'Wireless system for monitoring cave-back propagation', in C Carr \& $\mathrm{G}$ Chitombo (eds), Proceedings of the Seventh International Conference and Exhibition on Mass Mining, The Australasian Institute of Mining and Metallurgy, Melbourne, pp. 250-256.

Tang, B 2000, Rockburst Control Using De-stress Blasting, PhD thesis, McGill University, Montreal.

van As, A \& Jeffrey, RG 2000, 'Hydraulic fracturing as a cave inducement technique at Northparkes Mines', in G Chitombo (ed.), Proceedings of MassMin 2000, The Australasian Institute of Mining and Metallurgy, Melbourne, pp. 165-172.

van As, A, Jeffrey, R, Chacón, E \& Barrera, V 2004, 'Preconditioning by hydraulic fracturing for block caving in a moderately stressed naturally fractured orebody', in A Karzulovic \& M Alfaro (eds), Proceedings of MassMin 2004, Chilean Engineering Institute, Santiago, pp. 535-541.

Vejrazka, C 2016, 'Northparkes mines' current air blast risk assessment practices for block caving operations', in C Carr \& G Chitombo (Eds), Proceedings of Mass Mining 2016, The Australasian Institute of Mining and Metallurgy, Melbourne, pp. $257-263$.

Whiteman, D, Talu, S, Wilson, M, Watt, G, van As, A \& Kuiper, P 2016, 'Cave tracker flow monitoring system installation at Argyle diamond mine', in C Carr \& G Chitombo (eds), Proceedings of the Seventh International Conference and Exhibition on Mass Mining, The Australasian Institute of Mining and Metallurgy, Melbourne, pp. 479-490.

Wicaksono, D, Silalahi, K, Sryanto, I \& Vallejo, J 2012', 'Potential hazard map for the wet muck flow prevention at the Deep ore zone (DOZ) block cave mine, Papua, Indonesia', Proceedings of MassMin 2012, Canadian Institute of Mining, Metallurgy and Petroleum, Westmount, pp. 87-95.

Widijanto, E, Sunyoto, WS, Wilson, AD, Yudanto, W \& Soebari, L 2012, 'Lessons learned in wet muck management in Ertsberg East Skarn System of PT Freeport Indonesia', Proceedings of MassMin 2012, Canadian Institute of Mining, Metallurgy and Petroleum, Westmount.

Wilson, A, Purba, A \& Sjadat, A 2016, 'Progressing cave performance into the later stages of the Deep Ore Zone mine', in C Carr \& $\mathrm{G}$ Chitombo (eds), Proceedings of the Seventh International Conference and Exhibition on Mass Mining, The Australasian Institute of Mining and Metallurgy, Melbourne, pp. 285-292. 